\title{
Renata Dopierała
}

Uniwersytet Łódzki

https://doi.org/10.18778/1733-8069.9.2.10

\section{Recenzja}

\section{Piotr Sztompka(2012) Socjologia. Analiza społeczeństwa. Wydanie nowe poszerzone. Kraków: Społeczny Instytut Wydawniczy Znak}

Renata Dopierała, socjolog, adiunkt w Katedrze Socjologii Kultury Uniwersytetu Łódzkiego. Jej zainteresowania naukowe koncentrują sie wokół problematyki z zakresu mikrosocjologii oraz mediów i komunikacji. Prowadzi badania socjologiczne nad zjawiskami codzienności, prywatności i emocji.

\section{Dane adresowe autorki}

Katedra Socjologii Kultury Instytut Socjologii

Wydział Ekonomiczno-Socjologiczny

Uniwersytet Łódzki

ul. Rewolucji 1905 r. nr 41/43

90-214 Łódź

e-mail: renata_dopierala@poczta.onet.pl niu wcześniej prezentowanych treści (s. 19). Poza tym większa jest liczba ilustrujących omawiane zagadnienia fotografii.

Napisanie podręcznika nie jest zadaniem łatwym. Publikacji o takim charakterze stawia się określone wymagania, przede wszystkim musi w sposób jasny i klarowny, a także syntetyczny prezentować wiedzę z danej dyscypliny. Omawiany podręcznik wypełnia te zadania satysfakcjonująco. Podstawą książki były konspekty i notatki do wykładów prowadzonych przez lata $\mathrm{w}$ różnych ośrodkach naukowych, przez co materiał mógł być sprawdzony („przepracowany”) pod względem użyteczności dla studentów. Tekst główny uzupełniony jest licznymi - autorsko opracowanymi - diagramami obrazującymi przekrojowo (tzn. ujmując zjawiska z odmiennych teoretycznie perspektyw) wybrane zagadnienia, na przykład „działanie a reguły życia społecznego", „formy aktywności zbiorowej”, "typy identyfikacji z grupa”, ,fformy władzy i wpływu", "typy procesów”. Sylwetki ważniejszych socjologów zaprezentowane są $\mathrm{w}$ formie biogramów, które obrazują przebieg ich kariery naukowej, dokonania oraz główne poglądy i koncepcje. Każdy rozdział zakończony jest wykazem najważniejszych pojęć (wraz z ich definicjami), co jest niewątpliwie pomocne przy zapamiętywaniu materiału i ukierunkowuje uwagę na kluczowe zagadnienia (są one wyodrębnione przez pogrubienia $\mathrm{w}$ tekście). Stopień ich przyswojenia można skontrolować, rozwiązując test sprawdzający wiedzę (s. 673). W książce znajdziemy również polecane przez autora lektury poszerzające i uzupełniające problematykę prezentowaną $\mathrm{w}$ omawianym tomie oraz indeksy rzeczowy i osobowy, ułatwiające odnajdywanie stosownych treści. Oryginalnym pomysłem są zamieszczone fotografie wykonane przez auto- ra, obrazujące różne konteksty życia społecznego, między innymi „pejzaże miejskie”, „zjawisko konsumpcji”, „,kontakty interpersonalne”, ,komunikacja”, „nierówności”, „symbole”, „rytuały”. Zagadnienia, którymi interesują się socjologowie, są więc zaprezentowane metodą tradycyjną, jak i ilustracyjna, tworzac werbalno-wizualna całość. Od strony edytorskiej książka jest przygotowana bardzo starannie, wyróżnia ją estetyczna szata graficzna.

Na rynku wydawniczym istnieje kilkanaście podręczników socjologii zarówno takich, które są tłumaczeniami, jak i przygotowanych przez rodzimych autorów. Nie wikłając się w ich szczegółowe merytoryczne oceny, można je określić jako, w większości, podobne w swej formule. Propozycja Piotra Sztompki wyróżnia się na tle innych pod wieloma względami.

Na czym polega specyfika tego podręcznika? Dotyczy ona głównie sposobu przedstawienia zjawisk stanowiących przedmiotową dziedzinę socjologii. W „Przedmowie” autor sygnalizuje, że nie jest jego zamierzeniem „dostarczenie studentom informacji o różnych faktach dotyczących współczesnych społeczeństw" (s. 17), reprezentowanych przez zestawienia statystyczne, dane sondażowe i tym podobne, choć takiej wiedzy w odmienny sposób dostarcza. Jaki był zatem zamysł autora? „Moim celem jest nauczenie studentów [...] języka, a także szczególnej wyobraźni teoretycznej pozwalającej lepiej orientować się w otaczającym świecie społecznym i wyraźniej widzieć w nim miejsce i szanse życiowe" (s. 17). Cele wskazane przez Sztompkę były zatem trojakie. Po pierwsze, (typowa dla podręcznika) prezentacja formuł definicyjnych i koncepcyjnych pozwalających analizować, wyjaśniać i interpretować różne wymiary rzeczywistości. Znajomość mechanizmów funkcjonowania społeczeństwa i prawidłowości 
w nim zachodzących umożliwia - to cel drugi - zastosowanie tej wiedzy w nawiązywanych przez jednostki interakcjach i podejmowanych działaniach społecznych. Socjologia jest tutaj potraktowana nie jako wąska, hermetyczna dyscyplina naukowa, której kategorie opisowe zrozumiałe są dla nielicznych. Instrumentarium teoretyczne wypracowane przez socjologów autor nakłada/nadbudowuje na zasoby „wiedzy podręcznej” aktorów społecznych, na potoczne intuicje i tłumaczenia życia społecznego. Wyraźnie dostrzegalna jest tu specyficzna właściwość socjologii - dyscypliny, której ustalenia dotyczą działających i doświadczających jednostek, co sprawia, że może być ona przez nie wykorzystywana do organizacji codziennej egzystencji. Po trzecie, takie pragmatyczne spojrzenie na socjologię jest ważne w kontekście praktyk usensownienia i urefleksyjnienia indywidualnej „lokalizacji” w świecie.

O odmienności tomu świadczy także kilka innych elementów. Zgodnie z intencją autora - niedostarczania ilościowych informacji o faktach - dominuje styl eseistyczny, miejscami przypominający utrwalony wykład, przeplatany dygresjami i anegdotami. Ponieważ są one związane z prezentowanym tematem, są punktem odniesienia dla analiz teoretycznych omawianych zagadnień; ich rolę można określić jako dydaktyczną. Analogiczną funkcję pełnią bardzo licznie przytaczane - znów niestandardowo - przykłady zaczerpnięte z życia, z biografii autora: opisy potencjalnych/hipotetycznych zdarzeń, zachowań, sytuacji obrazujących pojęcia, procesy, problemy społeczne. Wiąże się z tym kolejna właściwość - w tak obszernym podręczniku nie znajdziemy wielu oryginalnie sformułowanych definicji czy wskazania odmiennych sposobów ujmowania zjawisk, niewielka jest także liczba przywoływanych źródeł bibliograficznych. Przyjęta przez Sztompkę formuła to przede wszystkim relacjonowanie (poprzez wyjaśnianie i tytułowe analizowanie), w jaki sposób różne aspekty rzeczywistości są kategoryzowane przez teoretyków życia społecznego.

Jaka jest struktura nowego wydania? Książka składa się z siedmiu części, 28 rozdziałów i liczy łącznie z bibliografią 728 stron. Główne bloki tematyczne to: "Aktywność człowieka”, "Całości społeczne”, „,Kultura”, „Podziały społeczne”, „Funkcjonowanie społeczeństwa”, „Zmienność społeczna”, „Społeczeństwo współczesne". Dyskusyjna jest zawartość niektórych części, jednak biorąc pod uwagę specyfikę społeczno-kulturowa, wzajemne przenikanie się zjawisk, można uznać, że przyporządkowanie poszczególnych kwestii jest do pewnego stopnia umowne. Porównując sposób ułożenia rozdziałów, nastąpiły nieznaczne przesunięcia względem wydania wcześniejszego - ten zaprezentowany w pierwszym wydaniu wydaje się bardziej logiczny (będzie to sygnalizowane w stosownym miejscu).

Rozdział pierwszy to prezentacja historii dyscypliny, jej relacja do przedsocjologicznej refleksji na temat zjawisk społecznych. Autor przedstawia najważniejsze paradygmaty, przywołuje alternatywne ujęcia klasycznego przedmiotu socjologii, czyli społeczeństwa. Materiał obejmujący rozległa czasowo perspektywę i szeroki zakres tematyczny został wyłożony w sposób zwięzły, co wymaga podkreślenia i uznania. Część I - „Aktywność człowieka” - jest najbardziej obszerna; obejmuje omówienie zróżnicowanych form życia ludzkiego, począwszy od najprostszych, incydentalnych zachowań poprzez coraz bardziej komplikujące się działania społeczne, interakcje, stosunki społeczne, organizacje, struktury, skończywszy na działaniach masowych, zachowaniach zbiorowych i ruchach społecznych. W stosunku do poprzedniego wydania część ta jest poszerzona o „Kapitał społeczny" (rozdział 8), w odniesieniu do którego można postawić pytanie, dlaczego jest umieszczony w tym miejscu. W tej części pojawia się także paragraf 5 związany z zaufaniem rozpatrywanym wraz ze zjawiskiem więzi (,Więzi moralne i zaufanie"). Do tematu zaufania autor wraca w rozdziale 14 (część III „Kultura”), tym razem koncentrując się na „Kulturze zaufania”. Wydaje się, że tematyka zaufania w wymiarze zarówno indywidualnym, jak i społecznym mogłaby być ujęta $\mathrm{w}$ jednym rozdziale (tak było w wydaniu wcześniejszym), poza tym kwestia zaufania jako elementu istotnego dla funkcjonowania zbiorowości mógłaby znajdować się w części noszącej właśnie taki tytuł (część V).

Nie do końca przekonujące jest kryterium oddzielające część I i II; treści z części pierwszej autor określa jako perspektywę „działaniową", podczas gdy część drugą charakteryzuje optyka "składowa" (są to odpowiednio ujęcia: społeczeństwo tworzone przez działania versus społeczeństwo złożone z jednostek). Niemożliwe jest rozłączne rozpatrywanie tych dwóch punktów widzenia (jeśli, to tylko analitycznie), o czym zresztą Sztompka wspomina, sygnalizując, że są one komplementarne i w istocie „mówimy ciągle o tym samym" (s. 234). Można także zapytać, dlaczego dociekania na temat struktury społecznej znalazły się w części I, a nie w części II - „Całości społeczne”, w której autor szerzej podejmuje właściwie tylko zagadnienie grup społecznych (to jak są definiowane, jakie są ich właściwości, co odróżnia je od innych zbiorowości, jak można je klasyfikować, jakie istnieją ich typologie, co charakteryzuje dynamikę grupową) i w mniejszym stopniu innych form zbiorowości (kategorie, organizacje, populacje). Nowy, dodany paragraf to szczegółowo opisa- ne dwie „,biegunowe”, ale znaczące grupy społeczne - rodzina i naród. Autor wskazuje na brak jednolitych kryteriów, według których można definiować naród, ale problemem jest sama klasyfikacja narodu jako grupy społecznej. Przyjmując, że jednym z kluczowych wyznaczników charakteryzujących grupe społeczną jest cecha zachodzenia interakcji między jednostkami (por. Hare 1976 za: Szmatka 2008: 41), to traktowanie narodu jako grupy nie jest do końca uprawnione. $\mathrm{W}$ takim rozumieniu termin „grupa społeczna" zarezerwowany byłby jedynie dla małych grup, w których bezpośrednie oddziaływania międzyjednostkowe są możliwe. Zwraca na to uwagę między innymi Barbara Szacka (2003: 186), przywołując pogląd Mertona kwestionującego określenie "grupa narodowa" ze względu na brak interakcji społecznych.

Zawartość pozostałych działów przedstawia się następująco: w części dotyczącej kultury znajdziemy między innymi tradycyjne rozważania na temat wielości sposobów definiowania kultury, kulturowego zróżnicowania form życia ludzkiego, mechanizmów wytwarzania kultury, elementów składowych kultury i ich oddziaływania. Tematyka kultury to także tradycja, język, przejawy świadomości społecznej (szczegółowo, odrębnie omówiona religia i nacjonalizm) oraz zasady konstruowania i działania systemu aksjonormatywnego w odniesieniu do działań społecznych. Autor opisuje typowe mechanizmy regulacji społecznej, jakimi są: normy, wartości, obyczaje, moralność, prawo, procesy instytucjonalizacji, wskazując na ich kluczową, z perspektywy funkcjonowania zbiorowości, rolę. Z problematyką utrzymywania ładu społecznego wiążą się zwykle postawy prezentowane przez jednostki, czyli dewiacja i konformizm; tak jest też w tym przypadku. W tej części pojawia się 
również wspomniane wcześniej - nieco problematyczne w moim odczuciu - zjawisko zaufania. Wielość wątków kulturowych oddających jej wieloaspektowe rozumienie sygnalizują takie wprowadzone kategorie, jak: „kultura grupowa”, „tożsamość kulturowa”, „kontakt kulturowy”, „dysonans kulturowy", „zmiana kulturowa”, „pluralizm kulturowy", ,kultury lokalne”, ,k,kontrkultura”.

Część czwarta to „Podziały społeczne”; składa się na nią omówienie różnych wymiarów nierówności dostrzegalnych w życiu społecznym (zarówno tych w ujęciu tradycyjnym: klasy, warstwy, jak i bardziej współczesnym, głównie płeć, zawód, etniczność). Jest tu również refleksja na temat czynników wytwarzających nierówności, ich funkcji oraz teorie je wyjaśniające. Autor omawia także hierarchiczny wymiar nierówności - stratyfikację i ruchliwość społeczną oraz szczególnego rodzaju dysproporcje między jednostkami w zakresie dostępu (lub jego braku) do władzy (jej typy, formy legitymizacji).

Wspominana już kilkakrotnie część V poświęcona jest bardzo obszernemu zagadnieniu, jakim jest funkcjonowanie społeczeństwa. Kluczowe w tym kontekście są dla autora proces socjalizacji (jej rodzaje i mechanizmy, agendy socjalizacyjne, proces internalizacji itp.), zjawisko kontroli społecznej (głównie teoria naznaczania społecznego) i proces instytucjonalizacji. Obecność dwóch ostatnich elementów wskazuje, że w tej części mógłby znaleźć się rozdział dotyczący systemu aksjonormatywnego (zamieszczony w części III poświęconej kulturze), w którym zostały wprowadzone wątki związane z problematyką dewiacji.

Strukturalne warunki życia zbiorowego (o których była mowa w poprzednich częściach) dopełnia perspektywa dynamiczna - część VI „Zmienność spo- łeczna" - czyli obraz rzeczywistości ujmowany przez pryzmat społecznych przeobrażeń i transformacji. Autor rozpoczyna od omówienia zjawisk zmiany społecznej, procesu, rozwoju i postępu społecznego, by przejść do teorii wyjaśniających mechanizmy zmiany społecznej (rozdział 24. „Klasyczne wizje dziejów"), między innymi teorie ewolucji, modernizacji, cykli dziejowych, społeczeństwa postindustrialnego. Pojawia się tu także zagadnienie rewolucji (ujęcia, modele, przebieg), ciekawa kwestia traumy związanej ze zmianą społeczną oraz diachroniczny wymiar funkcjonowania społeczeństwa (rozdział 23. „Czas w społeczeństwie”).

Część VII dotyczy społeczeństwa współczesnego. Autor przywołuje dychotomię tradycyjność/nowoczesność, przy użyciu której próbuje uchwycić specyfikę tej ostatniej. Nowoczesność jest analizowana w wymiarach społecznym, kulturowym, indywidualnym (osobowościowym), ekonomicznym, podkreślane są także jej negatywne aspekty. „Ekspansywność i dynamizm” nowoczesności wymaga skonceptualizowania wyłaniającej się jej „nowej" formy - Sztompka odwołuje się tu głównie do koncepcji „późnej nowoczesności” rozwijanej przez Anthony'ego Giddensa. Ostatni rozdział tej części to szczegółowo przedstawione zjawisko globalizacji (teorie, wizje, wymiary).

W układzie treści zawartych $\mathrm{w}$ podręczniku dostrzegalne są zainteresowania autora między innymi socjologią wizualną (wizualny aspekt rzeczywistości podjęty jest $\mathrm{w}$ rozważaniach na temat współczesności), problematyką zaufania społecznego czy zmian społecznych, rozwijane w odrębnych publikacjach.

Przy dążeniu do osiągnięcia postulowanego przez Maxa Webera ideału obiektywności nauki każdą publikację cechuje to, że wiedza, szczególnie socjologiczna, jest $\mathrm{w}$ pewien sposób przefiltrowana przez indywidualną perspektywę naukowca-badacza. W omawianym tomie ilustracją tej tendencji jest między innymi częste jednostronne rozumienie pojęć i tłumaczenie aspektów rzeczywistości przy niedostatecznym sygnalizowaniu, że jest to jedna z wielu możliwości interpretacyjnych. Socjologia jest wszak dyscypliną wieloparadygmatyczną - mnogość teorii daje sposobność ujmowania, opisywania i wyjaśniania zjawisk z kilku, czasem odmiennych i sprzecznych, perspektyw. Ze względu na przekrojowy charakter każdego podręcznika i zróżnicowanie zawartej w nim problematyki nie jest oczywiście możliwe przywoływanie historii formowania się pojęć czy wskazywanie wszelkich alternatywnych interpretacji zjawisk; konieczny jest tu wybór optyki szczególnie bliskiej badaczowi czy dokonywanie pewnych uogólnień, niemniej poczucie fragmentaryczności pozostaje. Jako przykład może posłużyć definicja kręgu społecznego zaproponowana przez Sztompkę: „niezależnie od konkretnych osób, każdą pozycję społeczną otacza krąg innych pozycji powiązanych z nią typowymi dla niej stosunkami społecznymi. Proponuję, aby dla opisania tej konfiguracji pozycji przyjać nazwę krąg społeczny" (s. 146). Poza znaczeniem "pozycyjnym" kręgi społeczne to także szczególne typy zbiorowości (m.in. kręgi przyjacielskie i koleżeńskie), o niewielkiej liczebności, oparte na bezpośrednich, niesformalizowanych stycznościach i nieposiadające wyraźnej zasady odrębności (Szczepański 1972: 255-258)

Ponadto, niektóre pojęcia funkcjonują w pewnej „próżni afiliacyjnej”, jako ogólnie używany zasób wiedzy, a wymagałyby - moim zdaniem - umiejscowienia ich $\mathrm{w}$ polu kontekstowym i autorskim, czyli wskazania ich genezy. Dotyczy to między innymi części poświęconej kulturze i takich zjawisk oraz odpowiadających im terminów, jak „,konfiguracja kulturowa”, ,relatywizm kulturowy” czy „przeżytki kulturowe". Choć wywodzą się one z odrębnej dyscypliny - antropologii kulturowej, to są często wykorzystywane $\mathrm{w}$ dociekaniach socjologicznych i znajomość źródeł, identyfikacja kategorii pojęciowych z ich twórcami byłaby pożądana.

Także niektóre interpretacje koncepcji i teorii dokonywane przez autora mogą być przyczynkiem do dyskusji i polemiki, szczególnie światopoglądowej. Wspomnę tu o dwóch - w moim odczuciu najbardziej istotnych kwestiach.

Na stronie 25 czytamy o destrukcji naukowej socjologii dokonującej się pod wpływem postmodernizmu, która jednak „na szczęście” marginalnie na nią wpływa i stanowi współcześnie przemijającą w znacznym tempie „dewiację myślową". Pomijając uprawnione indywidualne opinie na temat prądu myślowego określanego mianem „postmodernizm", a także jego żywotności, nie należy, jak sądzę, dokonywać jego zupełnej i całościowej deprecjacji. Autor nie uznaje postmodernizmu za teorię naukową (i słusznie, bo nią nie byt/jest) z tego względu, że nie pozwala on na dokonywanie systematycznego i analitycznego opisu społeczeństwa, a tym samym formułowanie praw (s. 632). Paradoksalnie, postmodernizm kwestionował analityczne roszczenia socjologii i krytykował ją jako naukę, jednak pytania, które postmoderniści stawiali (por. Turner 2004: 692-694), diagnozy, których dokonywali, stały się relatywnie trwałym elementem myślenia o współczesności. Cechy rzeczywistości społeczno-kulturowej dostrzegane przez postmodernistów i wymieniane przez Sztompkę to między innymi dekonstrukcja i implozja tradycyjnych 
uwarunkowań społecznych, konsumpcjonizm, symulakry i hiperrzeczywistość przeniknięta obrazami, spektaklami, wizjami, znakami, których wielość prowadzi do chaosu (s. 632). Ostatnie właściwości zasługują na szczególne podkreślenie; są one w różnym zakresie „składowymi" kultury wizualnej, która jest już przez autora waloryzowana pozytywnie i traktowana jako dominujący aspekt współczesności (s. 637-646).

Podobnie autor odnosi się - co jest zrozumiałe w kontekście powiązania obu kategorii - do „ponowoczesności", traktując ją jako radykalne zerwanie z wcześniejszymi fazami rozwoju społecznego. Nie jest to jednak jedyne rozumienie, jakkolwiek najczęściej przytaczane. W Encyklopedii socjologii czytamy, że termin ten obejmuje spektrum poglądów głoszących, że:

ponowoczesność jest z gruntu nowym typem społeczeństwa i jej nadejście oznacza kres nowoczesności, poprzez pogląd, że ponowoczesność jest nadal nowoczesnością, tyle że pozbawioną złudzeń, jakie mąciły jej obraz na etapie „klasycznym”, aż do stanowiska, że ponowoczesność była od pierwszej chwili aspektem kultury nowoczesnej i czasy dzisiejsze uwypukliły tylko zawsze obecne, choć rzadko dostrzegane przedtem aspekty - przyznały im rolę centralną, miast przejściowej i marginesowej. (Bauman 1999: 355)

Współczesność to niedostrzegalna wcześniej dynamika zmian społecznych, przeobrażenia wielu elementów rzeczywistości dokonujące się na nieporównywalną skalę - z tym stwierdzeniem zgadzają się właściwie wszyscy. Słuszny wydaje się więc pogląd Jerzego Szackiego, że drugorzędne znaczenie miałaby nadana im nazwa;

jedni będą woleli „ponowoczesność”, inni na przykład „szczytową postać nowoczesności”, „W pełni rozwiniętą nowoczesność” lub, dajmy na to, „nowoczesność refleksyjną". [...] Postmodernistów cechuje bardziej skłonność do przesady i egzaltacja niż bezwzględna swoistość podejmowanej problematyki. (Szacki 2002: 918)

Drugi wątek polemiczny związany jest z przekonaniami na temat równowartości kultur, podawanej jako przykład jednej z odmian tolerancji. Według autora pogląd ten został wprowadzony przez ideologię skrajnie liberalną jako „poszerzenie” istniejącego założenia o różnorodności kulturowej. Implikacją tego stanowiska jest odrzucenie wartościującej oceny kultur i eliminacja krytyki specyficznych i lokalnych uwarunkowań kulturowych. Na stronie 304 czytamy: „[t]erminy sugerujące niższość i wyższość, coś co gorsze i lepsze, zacofane i postępowe, prymitywne i rozwinięte, barbarzyńskie i cywilizowane - nie mają prawa bytu w słowniku zwolenników tzw. politycznej poprawności i zastąpione zostają jednym terminem «inny»". Założenie o równości kultur jest jednym z elementów składowych relatywizmu kulturowego (konkretnie relatywizmu normatywnego) i zostało wprowadzone za sprawą Franza Boasa (choć nie przez wszystkich jego uczniów przyjęte) już w pierwszych dekadach XX wieku. Jak pisze Melford Spiro:

ponieważ wszystkie sądy odnoszące się do relatywnych osiągnięć albo wartości różnych kultur sa etnocentryczne, jedynym ważnym normatywnym sądem jest ten, że wszystkie kultury posiadają równą wartość. Ten sąd jest prawdziwy w stosunku do kultur całościowych (kultura niemiecka w porównaniu z kulturą Hopi), do pojedynczych systemów kulturowych, takie jak religia [...] i w odniesieniu do poszczególnych stanowisk kulturowych. (2004: 28)

Konsekwencją tej postawy było odrzucenie teorii ewolucji społecznej i kulturowej i tym samym pojęcia postępu. „Ponieważ postęp jest sądem warto- ściującym, a wartości [...] są kulturowo relatywne, pogląd, że kultura zachodnia jest bardziej zaawansowana (dlatego wyższa) od kultur pierwotnych jest jedynie manifestacją zachodniego etnocentryzmu" (Herskovits 1972 za: Spiro 2004: 28). W związku z tym określenie "prymitywny" - jako nieuprawnione w tym kontekście - zostało wyeliminowane ze słownika antropologicznego na rzecz bardziej opisowego terminu „,kultura niepiśmienna”.

Analiza życia zbiorowego zaprezentowana w formie potoczystej opowieści, opatrzona wieloma komentarzami autorskimi ma zarazem pozytywne i negatywne aspekty. Pozytywne, gdyż obrazowe (właśnie

\section{Bibliografia}

Bauman Zygmunt (1999) Nowoczesność i ponowoczesność [w:] Encyklopedia socjologii, t. 2. Warszawa: Oficyna Naukowa.

Spiro Melford E. (2004) Relatywizm kulturowy i przyszzość antropologii kulturowej [w:] Nowicka Ewa, Kempny Marian, red., Badanie kultury. Elementy teorii antropologicznej. Kontynuacje. Warszawa: Wydawnictwo Naukowe PWN, s. 27-53.

Szacka Barbara (2003) Wprowadzenie do socjologii. Warszawa: Oficyna Naukowa. wyobrażeniowe) ujęcie rzeczywistości daje poczucie rozumienia mechanizmów jej funkcjonowania. Negatywne, bo to, co jest plastycznie przedstawione, może być - paradoksalnie - zbyt opisowe i mało konkretne, niektórym czytelnikom może nastręczać trudności z wyodrębnieniem tego, co jest naprawde istotne. Dlatego Socjologia. Analiza społeczeństwa Piotra Sztompki w mojej opinii jest skierowana raczej do czytelników (studentów), którzy mają potrzeby poznawcze rozbudzone $w$ większym niż przeciętny stopniu, którzy chcą poszerzyć, usystematyzować i ugruntować wiedzę, nie tylko przyswoić ją w sposób ukierunkowany, to znaczy w celu odtworzenia wiedzy na egzaminie. 